\title{
A Perspective on the College English Teaching Syllabus in China
}

\section{Chen Chuntian and Zhang Yujuan}

\section{Introduction}

College English, an English language course for non-majors in China, is one of the essential courses required for all college and university students. It has been playing an increasingly important role in training students to become qualified graduates from institutions of higher learning in China. At present, college graduates are expected to have an intermediate, or higher, proficiency in English. Therefore, College English Teaching has attracted much interest both at home and abroad. In order to provide a distinct picture of College English teaching in China, we begin with a general overview of the College English Teaching Syllabus (CETS, 1986) and then present some problems faced in implementing it.

\section{The Syllabus}

The revised College English Teaching Syllabus (CETS) was issued and published in 1986. It has been followed by virtually all the colleges and universities in China since then. The basic aim of the Syllabus is to help students develop

a relatively high ability in reading, a moderate ability in listening, and an elementary ability in writing and speaking so that the students will be able to employ English as a means for getting information necessary for pursuing their specialty. In addition, it will help the students lay a good foundation for further progress in studying English. (p. 1)

\section{The Rudimentary Stage}

College English Teaching is divided into two stages: the rudimentary stage and the specialty reading stage. The instruction in the rudimentary stage is divided into six bands, called College English Bands 1-6 (CEB 1-6). Each band has its specific requirements for vocabulary, listening, speaking, reading, and writing. In the rudimentary stage the students have to take a twoyear English course of 280 teaching hours, which includes intensive reading, extensive reading, rapid reading, focused listening, and writing. The students may begin their English study at different Band levels according to their respective proficiency in English. Those who pursue their bachelor's degree are required to complete College English Band 4 (CEB 4) and pass the 
College English Test Band-4 (CEBT-4) within the two-year study period. College English Band 6 (CEB 6) is offered on a voluntary basis to students who have comparatively high proficiency in English.

\section{The Specialty Reading Stage}

In order to ensure the continuity of their English study and to develop their skills in locating information related to their specialty through reading English books, journals, and other materials, the students are required to continue their English study from the fifth to seventh semester. So far there is no official syllabus for the Special Reading Stage. During this period the students are given guidance in reading technical English publications related to their specialty. The students may still go on to study in the Specialty Reading Stage even if they have not yet passed CEB 4.

\section{The Test}

The College English Test (CET) is a nationally standardized examination. College English Test Band-4 (CETB-4, 1987) and College English Test Band-6 (CETB-6, 1988) are organized and directed by the State Education Commission of China and have been in use since 1988. CETB- 4 and CETB- 6 are designed to test the students who have completed CEB-4 and CEB- 6 respectively. The aim is to test whether the students have fulfilled the requirements of the Syllabus. The tests are held twice each year in January and June.

The CET is a two-hour examination consisting of five parts: Listening Comprehension, Vocabulary and Grammatical Structure, Reading Comprehension, Cloze, and Writing.

CETB- 4 and CETB- 6 are recognized by the graduates' future employers in universities, hospitals, businesses, and government agencies. The College English Test (CET) provides the basis for evaluating English learning in colleges and universities; it also serves as a guarantor for carrying out the College English Teaching Syllabus (CETS). The number of students who participate in the Band 4 or Band 6 tests has increased with each passing year. Currently, it is the largest examination used in China. Since the initiation of the College English Test (CET) in 1988, the total number of the students taking part in CETB-4 and CETB- 6 reached 5,912,555 by June 1995. In the National College English Test held in June 1997, 779,248 students throughout the country sat for CETB-4 and 335,797 students participated in CETB-6.

\section{Two Levels of the Test}

The CET is divided into two levels, CETB-4 and CETB-6. Each student who takes the two-year College English Course is required to pass CETB-4 in order to meet the basic requirements of the Syllabus. Unless they pass CETB4 , students in leading colleges and universities may not receive their academic degree, and in most cases will not be allowed to graduate. On the 
other hand, more advanced students will have the opportunity to take CETB6 , an examination with higher requirements. CETB- 6 is administered on a voluntary basis to give students a chance to demonstrate their abilities. However, in certain cases it is a required examination. For example, the seven-year program at medical universities in China, including Norman Bethune University of Medical Sciences, requires students to pass CETB-6 in order to graduate. If students do not pass CETB- 4 or CETB- 6 the first time, they may repeat the tests. The students receive government certificates when they pass CETB- 4 or CETB-6.

\section{Reform of Test Items}

Since 1988, teachers of English in China have found weaknesses in the CET. Most of the test items have been multiple-choice questions that cannot test the students' skills in expressing themselves in correct spelling, idiomatic sentences, coherent paragraphs, and meaningful essays. As a result, the test format is not well balanced between objective and subjective items and does not provide a valid overall evaluation of the students' proficiency in English.

In order to improve the validity of the CET, to enable it to have a positive impact on classroom teaching, and to improve the students' English language skills, between 1993 and 1996 the CETB-4 and CETB-6 Committee of the State Education Commission of China studied the problems of the old test format and introduced new test items. In the process of reform, several subjective test items have been added.

Adding translation. Among the four reading passages in the Reading Comprehension Part of the CET, one or two sentences in each passage are underlined for translation. Students may refer to the context of the passages for their comprehension and translation. The aim of translation is to test students' accurate comprehension of the written English materials. Correct translation is based on accurate comprehension of the target language. Therefore, along with the multiple-choice questions in the reading comprehension test, translation adds another effective way of testing the students' competence in comprehension.

Adding short answers. In the Reading Comprehension Part, the former multiple-choice questions are partly replaced by short answers. The students are required to answer questions or fill in the blanks with words, phrases, or short sentences. This test format assesses students' competence in both comprehending the target language and expressing themselves in good written English.

Adding dictation. In the revised Listening Comprehension Part of the CET, there are two kinds of dictations: Spot Dictation and Compound Dictation. Spot Dictation requires the students to fill in the blanks with words or phrases in a passage of about 120 words. Compound Dictation requires the 
students first to fill in the blanks with words in a passage of about 250 words, then to write the main points of the dictated message.

The disadvantage of multiple-choice questions alone was that students could make random guesses. Adding dictation to the listening comprehension part can help eliminate students' bad habits of making random guesses. In addition, it can also help develop students' ability in spelling words, taking notes, and expressing themselves in written English. These four additional test forms, that is, translation, short answers, spot dictation, and compound dictation are used alternatively in each national test. To prevent teaching based on a fixed test format, the CETB- 4 and CETB- 6 Committee decides which form will be used before each test.

\section{Problems in Implementation}

Over a decade has passed since the inception of the Syllabus, which has made a positive contribution to the teaching of English to the non-English majors in China. However, colleges and universities in China have encountered problems that need solving if they are to upgrade their English teaching for the 21st century.

\section{A Gap between the Rudimentary Stage and \\ the Specialty Reading Stage}

Completing their study of CEB-4 does not prepare students well enough to move on to reading the technical English materials in their specialty courses.

There is a sharp turning for the students to shift from the common English to the special technical English. They felt there is a great discrepancy between the rudimentary English course they have just completed and the technical English they are expected to study. Therefore, there should be some bridge being built between the rudimentary course and the technical English learning process. (Miao, 1996, pp. 46-47)

\section{Vaguely Defined Writing Levels}

In the Syllabus the description of writing requirements is vague as far as the difference between the writing requirements for CEB- 4 and CEB- 6 is concerned. In terms of writing ability for CEB-4, the Syllabus stipulates that students' compositions should be coherent, without serious grammatical mistakes. On the other hand, in terms of the writing ability for CEB-6, the Syllabus states that the contents should be generally logical and coherent. Thus there does not seem to be much difference between the two expected standards of students' writing ability (Liu, 1991).

In addition, students' writing ability is rarely well developed. The average scores of CETB-4 and CETB-6 have always been around 6 out of 15 . 
In view of this low achievement, clearer and more specific guidelines should be added to the Syllabus in order to better direct the teaching of writing.

\section{Lack of Sufficient Consideration for Developing Oral Competence}

The Syllabus itself does not specify high requirements in the area of oral competence. Students are expected "to be able to carry on simple everyday conversations in English. In addition, the students should be able to ask and answer questions based on the text and retell the contents of the text" (CETS, 1986 , p. 2). Moreover, neither CETB-4 nor CETB-6 include test items to examine students' oral competence. The Syllabus and the test allow both the teachers and the students to deemphasize oral English proficiency in their courses.

Before 1986 it was common for many students to speak barely a few words of English after years of English study. There is ample evidence that the overall college English level in the country has improved since 1986 with the new Syllabus and CETB-4 and CETB-6. However, along with the development of the Chinese economy, there will be an increasing need for interpreters and translators in almost all workplaces. Therefore, improvement of students' oral competence has become increasingly urgent.

In order to improve oral proficiency, change can be made at least in two ways: (a) classroom activities should be student-centered; and (b) the language of classroom communication should be the target language (Wang, 1996). However, the question of whether an oral part can be included in the College English Test is being hotly debated around the country.

\section{Teaching to the Test}

In implementing the College English Teaching Syllabus (CETS), many colleges and universities have made the passing rate of the College English Test their top priority. This is not a pedagogically sound process for implementing a syllabus. The basic aim of college English teaching is to develop students' linguistic competence. The 280 teaching hours should be used primarily for improving the students' proficiency in English rather than emphasizing practice in taking CETB- 4 or CETB- 6 through simulated tests.

\section{Focus on Sentence-Level Grammar}

For many years teachers have emphasized the teaching of the language knowledge system at the sentence level. Currently more and more teachers recognize that language is a means for communication, and learning a foreign language means learning how to communicate with the target language. As people communicate at the discourse level, language teaching and learning should also include discourse-level knowledge and skills as well as sentence-level knowledge and skills. 
In conclusion, the CETB-4 and CETB-6 Committee of the State Education Commission of China has taken great steps to reform the test format. These efforts have begun to show good results. However, substantial ways must be found to solve many problems in order to improve the teaching of English to non-English majors in China. As China attempts to make the great leap forward into the 21st century, more effective English language teaching methods need to be developed to prepare Chinese students for the international stage.

\section{The Authors}

Chen Chuntian is the Deputy Director and an associate professor of English in the International Affairs Office, Norman Bethune University of Medical Sciences, Changchun, P.R. of China.

Zhang Yujuan is a professor of English in the English Department, Norman Bethune University of Medical Sciences, Changchun, P.R. of China.

\section{References}

College English Teaching Syllabus. (1986). Shanghai: Shanghai Foreign Language Education Press.

College English Test Band-4 Syllabus and Sample Test. (1987). Shanghai: Shanghai Foreign Language Education Press.

College English Test Band-6 Syllabus and Sample Test. (1988). Shanghai: Shanghai Foreign Language Education Press.

Liu, Xinmin. (1991). Suggestions on ELT in China's tertiary education. Foreign Language Teaching and Research Journal, 87(3), 73-75.

Miao, Junqiang. (1996). Some more thoughts on the National English Teaching Syllabus. Journal of the Foreign Language World, 62(2), 46-47.

Wang, Weijia. (1996). On raising the oral competence of non-English majors in colleges. Journal of the Foreign Language World, 63(3), 30-33. 